\title{
Performance Evaluation of Urban Cooperative Banks In India
}

\author{
Dr.K.V.S.N JAWAHAR BABU \\ Principal \\ KMM Institute of Technology \& Science Tirupati
}

\begin{abstract}
Abstrac: Urban co-operative banks (UCBs) are one of the vital segments of the banking industry of India. They essentially cater to the credit needs of persons of small means. Co-operative Banks are organized and managed on the principals of co-operation, self-help, and mutual help. These have been playing imperative role in Indian financial system with broad network in both urban and rural areas. Co-operative sector plays a very important role in fulfilling the directive principles and the objectives of Five Year Plans. The co-operative sector seeks to remedy the economic inequality and evils of concentration of income and wealth and thereby prevents the exploitation of the weaker sections by the stronger. Co-operation is a noble ideology and it aims at establishing a just civilized society. It lays the road to peace and abundance of wealth, both material and moral for all the citizens.
\end{abstract}

\section{Introduction}

There was a decline in the number of UCBs from 1,770 at the end of March 2008 to 1,721 at end the end of March 2009. This decline was an outcome of the consolidation process. The income tax paid for last fiscal by 1,780 urban cooperative banks and credit societies, mainly spread across Maharashtra, Andhra Pradesh, Gujarat, Karnataka and Tamil Nadu, was around Rs 1,000 crore. This shows the might of UCBs and their contribution to the people on the one side and to the exchequer and the society at large on the other.

The urban cooperative banking system has witnessed phenomenal growth during the last one and a half decades. Deposits in UCBs have increased by over 1100 percent from Rs. 8600 crore to over Rs.100, 000 crore, while advances have risen from Rs. 7800 crore to over Rs.65,000 i.e. by 733 percent during 1991-2005. According to National Association for Cooperative Urban Banks (NAFCUB), the total deposits \& lending of Co-operative Banks is much more than Old Private Sector Banks \& also the New Private Sector Banks. The joint stock Banks who had opened in the urban and semi urban areas did not yet cater to these small depositors. This absence of banking and credit facilities forced these groups to go to unscrupulous money lenders and private mortgagers who used to charge exorbitant interests or imposed almost non-repayable terms.

\section{Features of UCBs:}

- Important part of the financial system in India.

- democratically controlled,

- provide need based quality banking services,

- Essentially cater to the middle and lower middle classes and marginalized sections of the society.

- Procedural simplicity

- Close contact, informal atmosphere and local involvement

- Dual control, with a part of the powers vested in the State Government and a part with Reserve Bank.

- Heterogeneity among the banks in this sector in terms of size, geographical distribution, performance and financial strength

- Diversity among the urban cooperative banks in the levels of professionalism, standards of corporate governance and access to advanced technology

- Consequent upon the easing of licensing norms in May 1993, more than 800 licenses were issued for setting up urban cooperative banks. However, close to one-third of these newly licensed UCBs became financially weak within a short period. Today, there are evidences which clearly point out the weaknesses of UCBs such as lack of sound corporate governance, unconscionable lending, high levels of loan delinquency, inability to operate in a liberalized and competitive environment.

- Hindrances to the performance of UCBs

- Rising Competition: The Urban Co-operative Banks' (UCBs) segment, which was considered as one of the robust and fast expanding segments of the banking system till late 1990s, has become one of the weakest with regular cases of failures. It must be recognized that an UCB's basic organization is driven by the philosophy of co-operation and in a increasingly competitive environment an urban bank becomes more vulnerable on account of factors like size, location and compulsions to lend to a sector and thus, is deprived of scale economies. 
- Scams: Involvement of some of the UCBs in Gujrat and Andhra Pradesh in the share market scam in 2001 greatly lowered the level of public confidence in these banks. Even the existence of the Deposit Insurance and Credit Guarantee Corporation (DICGC), the upper insurance coverage is only up to Rs 1 lakh.

- Low Capital base: Further in spite of their strengths, the Urban Cooperative Banks also have a weakness in terms of generation of share capital. Thus the UCB sector is presently on a crossroad with these Banks finding it increasingly difficult to maintain their heterogeneous and unique cooperative character with the requirements of a strict regulatory regime and prudent banking norms as has been insisted upon by the RBI in the aftermath of the Gujrat and Andhra Pradesh experiences. in case of UCBs, the shareholders can withdraw their contribution to capital and shrink the capital of the bank and thereby limit its ability to increase risk weighted assets and expand business

- $\quad$ No clear-cut Loan and Investment Policy: In most of the UCBs in the state, there is virtually any Loan Policy not to speak of a comprehensive well laid out Loan Policy. The most important part of Loan Policy is the pre-credit appraisal part which is absent in the so called Loan Policy of many banks. The ultimate result of this type of mismanagement in and non appraisal of the risk in credit is non recovery of loans and assets and standard assets trickling down to substandard, doubtful and non-recoverable loss.

The fact remains that most of the UCBs has no policy of Investment. They are making investments based on their experience and on the basis of circulars and guidelines issued by the RBI from time to time but there are instances of violation of directives of RBI by some banks in the past by purchasing securities from fake brokers and ultimately the officers are entrapped in fraud case and money invested is turned into loss assets.

- $\quad$ Piling- up of NPAs: A high power committee constituted by RBI finds that the NPA levels in UCBs are disproportionately high, which is a major challenge to be tackled is. Like policy of Loans and Advance UCBs should have an Investment Policy and be updated in each year and approved in the BODs meeting.

- As a result of total mismanagement and frauds, the Non-Performing Assets - which do not yield any income increased abnormally and the banks became weak/sick.

\begin{tabular}{|c|c|c|c|c|}
\hline $\begin{array}{l}\text { THE FAILED BANKS } \\
\text { - NAKED TRUTH } \\
\text { Name of the UCB }\end{array}$ & $\begin{array}{l}\text { No. Of } \\
\text { Deposi } \\
\text { tors }\end{array}$ & $\begin{array}{c}\text { Deposi } \\
\text { ts }\end{array}$ & $\begin{array}{c}\text { Non- } \\
\text { Perfor } \\
\text { ming } \\
\text { Assets } \\
\text { (NPA) }\end{array}$ & $\begin{array}{c}\text { Capital to } \\
\text { Risk } \\
\text { Weighted } \\
\text { Asset Ratio } \\
\text { (CRAR) }\end{array}$ \\
\hline Krushi & 8,247 & $\begin{array}{l}\text { Rs. } 35 . \\
69 \text { Cr. }\end{array}$ & $\begin{array}{c}32.22 \\
\text { Cr. }\end{array}$ & N.A. \\
\hline Charminar & $\begin{array}{c}1,38,0 \\
00\end{array}$ & $\begin{array}{c}\text { Rs. } 297 \\
\text { Cr. }\end{array}$ & $\begin{array}{c}63.20 \\
\% \\
(64.52 \\
\text { Cr })\end{array}$ & N.A. \\
\hline Vasavi & $\begin{array}{c}1,38,5 \\
11\end{array}$ & $\begin{array}{c}\text { Rs. } 143 \\
\text { Cr. }\end{array}$ & $\begin{array}{c}67.20 \\
\% \\
(84.64 \\
\text { Cr. })\end{array}$ & $0.25 \%$ \\
\hline Prudential Bank & $\begin{array}{c}1,86,7 \\
65\end{array}$ & $\begin{array}{l}\text { Rs. } 451 \\
.39 \mathrm{Cr} \text {. }\end{array}$ & $\begin{array}{c}66.50 \\
\% \\
(300.2 \\
2 \text { Cr. })\end{array}$ & $-23.6 \%$ \\
\hline
\end{tabular}

Dual Control: The multiplicity of regulation and control from central and state bodies hinders the smooth and efficient functioning of UCBs on the one hand, and the absence of administrative control by the government authorities leads to arbitrary usage of funds, and putting stakeholders' interests at stake.

Poor governance: UCBs borrowers have a significant say in the managements of the banks. This has the potential of influencing the Boards to take decisions that may not always be in the interest of the depositors who constitute the most important stakeholders of a bank.

Uneven geographical dispersal: Uneven geographical dispersal of UCBs in few states such as Maharashtra, Gujarat, Karnataka, Andhra Pradesh and Tamil Nadu is evident from the fact that those states account for over $80 \%$ of urban cooperative banks presence and $75 \%$ of their total deposits. The type of reach cooperative banks has in our country and the type of customized services they can offer at the local level, the potential is tremendous. But, the question is have we achieved the true potential? The answer to the question to a certain extent is negative. 


\section{Common Irregularities Reported In Some Ill Managed Cooperative Banks:}

- Siphoning of funds by directors

- Term loans were converted into overdrafts and loan amounts were enhanced without any formal request from the borrowers.

- Sub-prime mortgage: Huge amounts of loans were sanctioned on the basis of the properties mortgaged with the bank, which had fake and fabricated sale deeds and therefore had no legal value. There is an instance wherein a borrower obtained a loan of Rs.50 lakhs by mortgaging a Municipal Park in Hyderabad City. In yet another sensational instance, a borrower mortgaged the land belonging to Wakf Board and obtained a loan of Rs.2.5 crores. And there are instances, where crores were sanctioned even on the basis of nonexisting properties.

- Most of the properties mortgaged were grossly over valued by the valuators of the banks.

- Fictitious entries indicating repayment of huge amount of cash and subsequent withdrawal on the same day with a view to prevent the said amount from being classified as Non-Performing Assets (NPA).

- The application for sanction of big loans were received in the head office directly by Chairman / Managing Director and the loan amounts of crores of rupees were sanctioned on the same day without obtaining any verification reports from the field officers regarding viability of the project / business, repaying capacity, credit worthiness etc. of the applicant.

- The UCBs offered unviable very high interest rates as well as incentives to the depositors.

- The banks continuously defaulted in the maintenance of CRR and SLR.

- Ignoring the RBI directive, the Banks sanction huge loans to the prohibited and risky sectors.

- Borrowers with no capacity to run business and repay amounts are sanctioned huge loans.

- Loan proposals instead of routing through the Branch Managers were directly recommended by the Directors.

- In several instances crores of rupees were sanctioned to the individuals, who were not even income-tax payers.

- Advances were sanctioned for unproductive / consumption / ceremonial purposes.

- Excess drawl was allowed in many Over-Draft accounts.

- The system of internal audit do not exist in many of the banks.

\section{Conclusion}

Urban Cooperative Banking is a key sector in the Indian Banking scene, which in the recent years has gone through a lot of turmoil. Though some UCBs have shown credible performance in the recent years, a large number of banks have shown discernible signs of weakness. The operational efficiency is unsatisfactory and characterized by low profitability, ever growing non-performing assets (NPA) and relatively low capital base. Also urban cooperative banks have not been able to service the growing credit requirements of clients or the newer demands for loans in the field of personal finance. In the interest of healthy competition, the urban cooperative banks should be encouraged to grow. Thus a few bad eggs should not curb the growth of a key banking entity.

\section{References:}

[1]. Zulkhibri A Majid and Habibullah S Muzafar (2005): Determinants of 24 Deposit Taking Co-operatives' Failure in 1986: An Empirical Evidence, Asian-AfricanJournal of Economics and Econometrics, Vol. 5, No 2, 2005

[2]. Ramesha K (2003): Co-operative Banking and Financial Sector Reforms in IndiaAgenda for Future Research, International Conference on Mapping Co-operativeStudies in the New Millennium, British Columbia Institute for Co-operative Studies,

[3]. University of Victoria and International Co-operative Alliance, Victoria BC, Canada,May 28-31, 2003

[4]. Ramesha K (2004): Economic Reforms and the Performance of Co-operative Sector in India - Lessons for Future, International Association for the Economicsof Participation, 12th Biannual Conference, Saint Mary's University, Halifax, Canada,July 8-10, 2004

[5]. Ramesha K, Chipalkatti Niranjan and Rishi Meenakshi (2006): Who Failed Whom? An Empirical Assessment of Prudential Standards and Co-operative Banks inIndia, AEA-ASSA Annual Conference, January 6-8, 2006, Boston MA, USA

[6]. Reserve Bank of India: Report on Trend \& Progress of Banking in India (1993-94to 2004-05), RBI, Mumbai

[7]. Government of India (1998): Report of the Committee on Banking SectorReforms, RBI, MumbaiReserve Bank of India (1999): Report of the High Power Committee on UrbanCooperative Banks, RBI, Mumbai 